\begin{tabular}{cc}
\hline UNIVERSITAS AHMAD DAHLAN \\
JURNAL BIOEDUKATIKA \\
2338 h
\end{tabular}

\title{
Penerapan analogi pada perkuliahan genetika untuk menumbuhkan keterampilan penalaran ilmiah (scientific reasoning)
}

\author{
Yuyun Maryuningsih a, 1, ${ }^{*}$, Topik Hidayat ${ }^{\text {b, } 2 \text {, Riandi }}{ }^{\text {b, }}{ }^{3}$, Nuryani Y Rustaman ${ }^{\text {b, }} 4$ \\ ${ }^{a}$ Tadris IPA Biologi, IAIN Syekh Nurjati, Jalan Perjuangan, Karyamulya, Kota Cirebon, Jawa Barat 45131, Indonesia

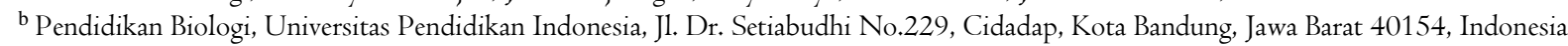 \\ ${ }^{1}$ yuyunmaryuningsih2014@gmail.com; ${ }^{2}$ topikhidayat@upi.edu; ${ }^{3}$ rian@upi.edu; ${ }^{4}$ nuryanirustaman@upi.edu \\ *korespondensi penulis
}

\begin{tabular}{ll}
\hline Informasi artikel & \\
\hline Sejarah artikel: & \\
Diterima & 29 Maret 2018 \\
Revisi & 26 Juli 2018 \\
Dipublikasikan & 21 November 2018 \\
\hline
\end{tabular}

Kata kunci:

Analogi

Keterampilan penalaran ilmiah Genetika \begin{abstract}
ABSTRAK
Keterampilan penalaran ilmiah yang merupakan keterampilan berpikir tingkat tinggi yang perlu dilatihkan pada mahasiswa calon guru untuk materi-materi genetika yang bersifat abstrak seperti topik materi genetik dan pindah silang. Penelitian ini merupakan studi pendahuluan dalam perancangan program perkuliahan genetika, untuk mengetahui penggunaan strategi dan metode yang tepat dalam beberapa materi genetika. Implementasi pembelajaran genetika dengan analogi diujikan secara terbatas pada tiga puluh tujuh mahasiswa Pendidikan Biologi yang mengambil mata kuliah genetika. Analogi dilakukan pada topik materi genetik dan pindah silang. Penerapan analogi pada model DNA dengan menggunakan bahan-bahan yang dapat digunakan dalam pembuatan model DNA dan analogi pada pindah silang dengan menggunakan lilin malam/plasticine. Profil keterampilan penalaran ilmiah siswa diukur secara skoring pada model DNA untuk topik materi genetik dan pindah silang. Data dianalisis secara kualitatif untuk melihat profil siswa dalam penalaran ilmiah. Hasil dari penelitian ini bahwa penggunaan analogi dalam pembelajaran genetika dapat diterapkan pada topik materi genetik dan pindah silang.
\end{abstract}

Key word: Analogy

Scientific reasoning skill

Genetics

\begin{abstract}
Analogies application of genetic course to arise scientific reasoning skills. Scientific reasoning skills were high-level thinking skills that need to be trained in prospective teacher students for abstract genetic material such as the topic of genetic material and crossovers. This research was a preliminary study in the design of the genetic lecture program, to find out the use of appropriate strategies and methods in some genetic material. The implementation of genetic learning by analogy was limitedly tested on thirty-seven Biology Education students who took genetics courses. The analogy was done on the topic of genetic material and crossovers. The application of analogies to DNA models using materials that can be used in making DNA models and analogies to crossovers using night candles/plasticine. Profiles of students' scientific reasoning skills are measured scoring on DNA models for the topic of genetic material and crossovers. Data were analyzed qualitatively to see students' profiles in scientific reasoning. The results of this study that the use of analogies in genetic learning could be applied to the topic of genetic material and crossovers.
\end{abstract}

Copyright (C) 2018 Universitas Ahmad Dahlan

\section{Pendahuluan}

Tantangan yang dihadapi guru dalam mengajarkan genetik yaitu istilah yang tidak digunakan secara umum dan beberapa istilah yang mirip tetapi bermakna berbeda, seperti DNA RNA, genotip - fenotip, dominan - resesif dan istilah lainnya. Beberapa siswa tidak mampu memahami beberapa istilah tersebut. Pemahaman kosakata genetika menjadi hal yang sangat penting dalam memahami genetika. Perkembangan di bidang genetika yang sangat pesat juga menjadi isu sosioscientific yang banyak diperbincangkan di masyarakat. Pemahaman terhadap genetik penting dimiliki oleh semua kalangan dalam menjalani hidupnya.

Beberapa keterampilan sangat dibutuhkan dalam menghadapi kehidupan dimasa depan. 
Keterampilan-keterampilan itu merupakan bekal dalam menghadapi segala permasalahan hidup. Keterampilan berpikir secara logis, rasional sangat dibutuhkan dalam menghadapi kehidupan di masa depan.

Pelaksana yang bertatapan dengan siswa secara langsung dalam sistem pendidikan nasional adalah para guru. Guru harus memiliki empat kompetensi yaitu kompetensi kepribadian, pedagogik, sosial dan profesional. Pembekalan guru untuk memperoleh keempat kompetensi tersebut dimulai sejak calon guru menempuh pendidikan sebagai mahasiswa calon guru. Mahasiswa calon guru biologi harus dibekali pengetahuan dan keterampilan yang memadai sebelum berperan sebagai guru biologi, dimana seorang pendidik seyogyanya adalah seorang ilmuwan (Jiménez-Aleixandre, 2014).

Di beberapa negara baik negara maju seperti negara-negara di Eropa dan Amerika maupun negara berkembang seperti Indonesia, pengembangan keterampilan untuk berpikir secara ilmiah salah satunya keterampilan berpikir tingkat tinggi (high order thinking skill) telah menjadi tujuan utama dari pendidikan pada umumnya dan pendidikan sains pada khususnya. Keterampilan penalaran ilmiah yang merupakan salah satu keterampilan berpikir tingkat tinggi adalah keterampilan dan kebiasaan berpikir sebagai inti dari literasi ilmiah, yang melibatkan: (1) kemampuan dan kebiasaan untuk berpikir sebagai usaha membangun pemahaman atau pengetahuan, (2) memahami konsep inti dan teori sebagai pemersatu ilmu pengetahuan, dan (3) kemampuan untuk berkomunikasi yang menginformasikan dan membujuk orang lain untuk mengambil tindakan yang berkaitan dengan konsep-konsep dan teori-teori (Zimmerman, 2000).

Penalaran ilmiah yang merupakan bagian dari penalaran logik banyak diteliti pada program pembelajaran kimia, fisika dan matematika tetapi jarang ditemukan pada biologi terutama konsepkonsep genetika. Penalaran ilmiah pada genetika juga perlu dibudayakan dalam pembelajaran sains seperti genetika.

Genetika merupakan mata kuliah yang sulit dipahami karena bersifat abstrak dan memerlukan perangkat laboratorium yang mendukung era genetika molekuler. Akan tetapi, fasilitas sarana dan prasarana laboratorium genetika yang mendukung tidak dimiliki oleh semua perguruan tinggi. Untuk itu perlu diupayakan pembelajaran genetika dengan menggunakan beberapa pendekatan atau model.

Keterampilan penalaran ilmiah perlu dilatihkan dan dibudayakan dalam pendidikan sains. Penalaran ilmiah yang meliputi pengetahuan konten, pengetahuan prosedural dan pengetahuan epistemik harus dimiliki oleh pendidik sains (Kind \& Osborne, 2017). Penalaran ilmiah merupakan pengetahuan meta analitik dalam proses pembelajaran (Engelmann, Neuhaus, \& Fischer, 2016) yang menjadi bekal calon pendidik ketika membelajarkan siswa.

Keterampilan penalaran ilmiah sangat diperlukan tidak hanya untuk para ilmuwan masa depan tetapi juga pada masa ini, dimana penalaran ilmiah dengan pengetahuan berbasis masyarakat merupakan keterampilan yang harus dimiliki oleh calon guru. Dasar keterampilan penalaran ilmiah semakin penting untuk membuat keputusan dalam kehidupan sehari-hari dan untuk berpartisipasi dalam kehidupan sosial. Keterampilan penalaran ilmiah perlu dilatihkan dan dibina dalam proses pendidikan terutama dalam pendidikan sains.

Menurut Shamos (1995) dimensi dari orang yang "literasi" yang benar-benar ilmiah adalah: (1) memahami proses ilmiah dari pengembangan pengetahuan, (2) memahami pentingnya observasi dan eksperimen dalam sains, (3) mampu mempertanyakan, (4) menggunakan logika untuk induksi dan deduksi, (5) mengandalkan tiga bukti, (6) memiliki pemahaman yang tepat tentang sifat sains, dan (7) memiliki pemahaman dasar tentang sejarah, nilai-nilai, dan asumsi sains. Dengan demikian, seorang calon guru juga diharapkan memiliki beberapa keterampilan tersebut. Oleh karena itu, perlu dilakukan upaya melatihkan beberapa keterampilan tersebut dalam pembelajaran.

Penggunaan filosofi dengan menumbuhkan pengetahuan epistemik siswa pada praktek pendidikan calon guru sains; salah satunya adalah praktek penalaran dalam proses pembelajaran (Janssen \& van Berkel, 2015; Lawson, 2004) sehingga siswa dapat lebih memahami beberapa konsep genetika (Kılıç \& Sağlam, 2014). Penggunaan analogi dalam praktek pembelajaran (Kaufman, Patel, \& Magder, 1996; Kind \& Osborne, 2017; Kılıç \& Sağlam, 2014; Kolodner et al., 2003) genetika dapat memahamkan beberapa konsep yang abstrak, dapat membantu siswa untuk lebih memahami genetika (Woody \& Himelblau, 2013). Penggunaan analogi dalam praktek pembelajaran dapat memahamkan genetika secara visual pada siswa (Bello et al., 2007; Goldschmidt, 2001), menyelesaikan berbagai permasalahan tentang topiktopik genetika (Cavallo, 1996; Woody \& Himelblau, 2013), dan meningkatkan penalaran ilmiah (Ding, Wei, \& Mollohan, 2016; Duncan, 2007; Lawson, 2004; Stiller et al., 2016).

Program perkuliahan genetika berjumlah 14 pertemuan. Beberapa diantaranya memuat topik 
berupa konsep abstrak. Pertemuan memuat konsep abstrak membutuhkan cara, metode, strategi dan inovasi dalam membelajarkannya pada calon guru sebagai bekal mereka untuk mempraktekkan dalam pembelajaran tentang konsep-konsep genetika kelak.

Penerapan analogi pada pembejaran genetika tentang konsep-konsep yang abstrak diharapkan mampu meningkatkan penalaran ilmiah calon guru pada konsep-konsep genetika yang abstrak tersebut. Dengan demikian perlu dirumuskan program perkuliahan genetika yang tepat dengan menerapkan analogi dalam pembelajaran.

Pembahasan terkait penelitian ini berpusat pada penerapan metode analogi dalam pembelajaran genetika dan kemampuannya untuk meningkatkan keterampilan penalaran ilmiah calon guru. Selain itu juga untuk mengetahui profil keterampilan penalaran ilmiah calon guru.

\section{Metode}

Penelitian ini merupakan penelitian pendahuluan yang dilakukan dengan metode survei dalam perancangan program perkuliahan genetika. Tujuan dari penelitian ini adalah mengetahui penggunaan strategi dan metode yang tepat dalam beberapa materi genetika yang bersifat abstrak.

Partisipan dalam penelitian ini adalah mahasiswa tingkat tiga calon guru biologi yang mengambil mata kuliah genetika di IAIN Syekh Nurjati Cirebon dengan jumlah partisipan 37 orang. Responden dipilih sesuai dengan kriteria yang telah ditetapkan. Penelitian ini dilakukan secara deskriptif kualitatif. Penerapan analogi pada perkuliahan dilakukan pada dua materi genetika yaitu topik materi genetik dan pindah silang.

Keterampilan penalaran ilmiah siswa diukur dengan menggunakan indikator penalaran ilmiah. Menurut Wenning \& Vieyra (2015) terdapat 16 framework dalam penalaran ilmiah. Framework tersebut dimodifikasi sebagai berikut: mendefinisikan masalah untuk dipelajari; mendefinisikan sistem yang akan dipelajari; merancang model analogi yang terkontrol; menafsirkan data untuk mernerapkan konsep abstrak yang menggunakan logika; menentukan jawaban atas suatu masalah; meringkas tujuan secara logis; menggunakan penalaran kausal untuk membedakan kebetulan dari sebab akibat; menggunakan penalaran proporsional untuk membuat prediksi; menghasilkan dan mengeavaluasi analogi; berpikir analogi; berpikir untuk mengasimilasi konsep dan berpikir dengan sengaja. Profil keterampilan penalaran ilmiah siswa diukur secara skoring pada model DNA untuk topik materi genetik dan pindah silang kemudian data dianalisis secara kualitatif untuk melihat profil siswa dalam penalaran ilmiah.

Tabel I. Framework keterampilan penalaran ilmiah

\begin{tabular}{|c|c|c|}
\hline $\begin{array}{c}\text { Kategori } \\
\text { keterampilan }\end{array}$ & $\begin{array}{c}\text { Level dalam } \\
\text { Taksonomi } \\
\text { Bloom }\end{array}$ & $\begin{array}{l}\text { Keterampilan proses } \\
\text { sains }\end{array}$ \\
\hline Integrated & Analisis & $\begin{array}{c}\text { Mendefinisikan suatu } \\
\text { masalah untuk dipelajari } \\
\text { Mendefinisikan tepatnya } \\
\text { sistem yang akan dipelajari } \\
\text { Merancang dan melakukan } \\
\text { penyelidikan ilmiah yang } \\
\text { terkontrol } \\
\text { Menafsirkan data } \\
\text { kuantitatif untuk } \\
\text { menetapkan tahapan yang } \\
\text { menggunakan logika }\end{array}$ \\
\hline Advanced & Evaluasi & $\begin{array}{c}\text { Menentukan apakah yang } \\
\text { dipilih adalah jawaban atas } \\
\text { masalah atau pertanyaan } \\
\text { cukup menentukan ukuran } \\
\text { dan atau unit } \\
\text { Meringkas untuk tujuan } \\
\text { logis membenarkan dasar } \\
\text { kesimpulan dari bukti } \\
\text { empiris } \\
\text { Menggunakan penalaran } \\
\text { kausal untuk membedakan } \\
\text { co-insidence dari sebab } \\
\text { dan akibat } \\
\end{array}$ \\
\hline Culmina-ting & Evaluasi & $\begin{array}{c}\text { Menyimpulkan secara } \\
\text { logis dari bukti yang } \\
\text { empiris } \\
\text { Menggunakan penalaran } \\
\text { kausal untuk membedakan } \\
\text { kebetulan dari sebab dan } \\
\text { akibat } \\
\text { Menggunakan data dan } \\
\text { matematika dalam } \\
\text { pemecahan masalah dunia } \\
\text { nyata } \\
\text { Menggunakan penalaran } \\
\text { proporsional untuk } \\
\text { membuat prediksi }\end{array}$ \\
\hline & Sintesis & $\begin{array}{c}\text { Menghasilkan dan } \\
\text { mengevaluasi analogi } \\
\text { Menghasilkan prediksi } \\
\text { melalui proses deduksi } \\
\text { Berpikir analogi } \\
\text { Berpikir untuk } \\
\text { mengasimilasi konsep } \\
\text { Berpikir dengan sengaja }\end{array}$ \\
\hline
\end{tabular}

Pemilihan framework penalaran ilmiah menurut Wenning \& Vieyra (2015) karena framework ini mengintegrasikan Bloom revisi dan keterampilan proses sains (Tabel 1). Framework ini melingkupi kinerja siswa dalam melaksanakan pembelajaran berdasarkan proses sains dan aktivitas berpikir secara kognitif. Dengan demikian, level keterampilan penalaran ilmiah dapat diukur. 
Teknik analisis data dilakukan secara deskriptif kualitatif dengan menganalisa profil keterampilan penalaran ilmiah pada siswa dengan Rumus 1:

$$
P=\frac{\sum \text { score }}{64} x 100
$$

Keterangan:

$\mathrm{P}=$ Profil keterampilan penalaran ilmiah siswa

\section{Hasil dan pembahasan}

\section{Penerapan analogi dalam pembelajaran genetika}

Penerapan analogi pada beberapa materi genetika dipilih dengan pertimbangan bahwa materi genetik memerlukan analogi penggambaran bentuk model DNA yang tepat dan dapat mewakili komponen-komponen dalam model struktur double heliks DNA. Selian itu, diperlukan mekanisme atau proses yang konkrit guna menggambarkan keterwakilan proses pindah silang pada kromosom, dengan menggunakan lilin malam sebagai bahan untuk model kromosom.

Analogi model DNA dapat divisualisasikan dengan menggunakan bahan-bahan bekas pakai dan dibuat model DNA Watson \& Cricks. Proses pindah silang dibuat dengan menggunakan lilin malam, yang dapat dibentuk dan diubah-ubah bentuk serta posisinya tergantung dari tipe pindah silang. Warna malam yang berbeda-beda mempermudah analogi untuk visualisasi proses pindah silang pada kromosom.

Penggunaan analogi pada model DNA dan pindah silang dapat dilihat pada Gambar 1 dan Gambar 2.

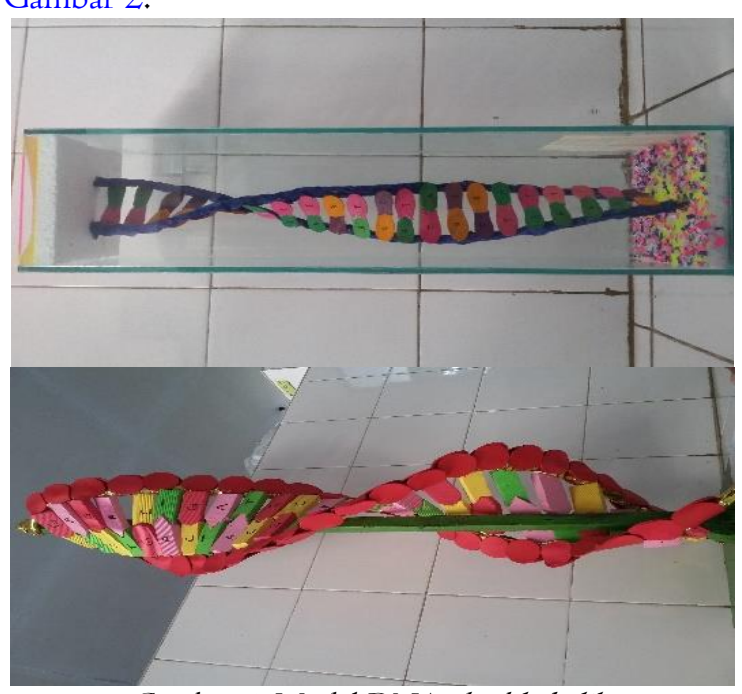

Gambar I. Model DNA double heliks

Gambar 1 menunjukkan model double heliks DNA hasil mahasiswa calon guru. Model dibuat menggunakan lilin malam yang berwarna-warni. Warna yang digunakan memudahkan mahasiswa calon guru untuk memvisualisasikan bentuk dan karakteristik dari double heliks DNA.
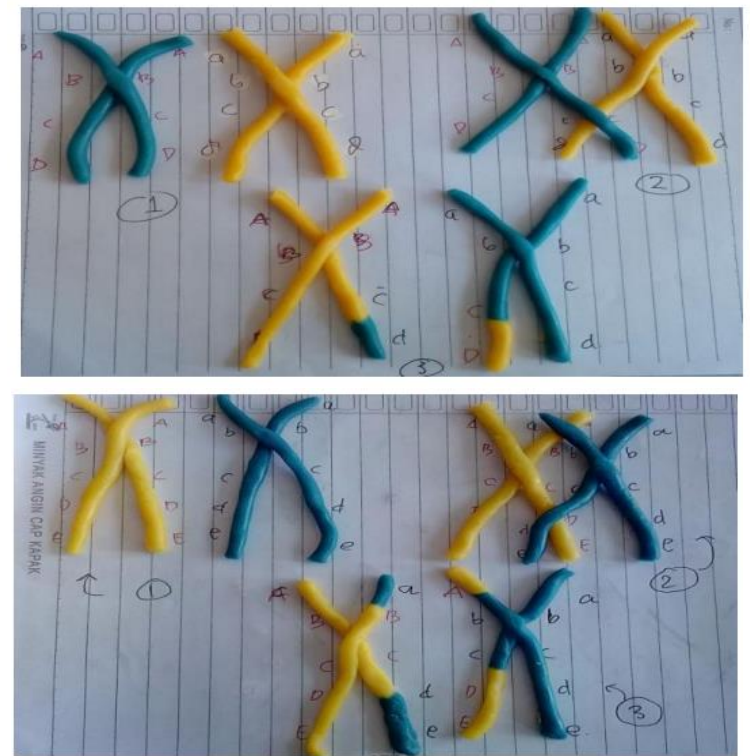

Gambar 2. Proses pindah silang dengan menggunakan lilin malam

Gambar 1 dan Gambar 2 menunjukkan hasil dari analogi visualisasi model DNA dan proses pindah silang pada kromosom yang dibuat oleh mahasiswa calon guru. Visualisasi untuk konsepkonsep yang abstrak sangat membantu siswa dalam membedakan struktur DNA double heliks. Siswa mampu membedakan basa purin dan pirimidin penyusun DNA serta dapat memahami proses pindah silang tunggal dan ganda pada kromosom yang mengalami pindah silang. Visualisasi konsep yang abstrak dengan penggunaan analogi tepat digunakan pada pembelajaran genetika (Bello et al., 2007; Goldschmidt, 2001).

Analogi dalam pembelajaran genetika dapat digunakan untuk beberapa konsep abstrak seperti materi genetik dan pindah silang. Hal ini karena kedua konsep tersebut merupakan konsep yang memerlukan proses berpikir secara nalar untuk dapat memvisualisasikan bentuk model struktur DNA dan proses pindah silang.

Profil keterampilan penalaran ilmiah mahasiswa calon guru

Berikut keterampilan penalaran ilmiah yang diukur berdasarkan indikator framework scientific reasoning menurut Wenning \& Vieyra (2015) pada beberapa kinerja mahasiswa calon guru:

I) Keterampilan penalaran ilmiah mahasiswa pada konsep materi genetik

Keterampilan penalaran ilmiah calon guru pada konsep materi genetik didapat dari model DNA yang dibuat secara berkelompok. Model DNA dibuat menggunakan bahan-bahan yang dapat 
memvisualisasikan struktur double heliks DNA dengan baik. Keterampilan penalaran ilmiah mahasiswa dijabarkan pada Gambar 3.

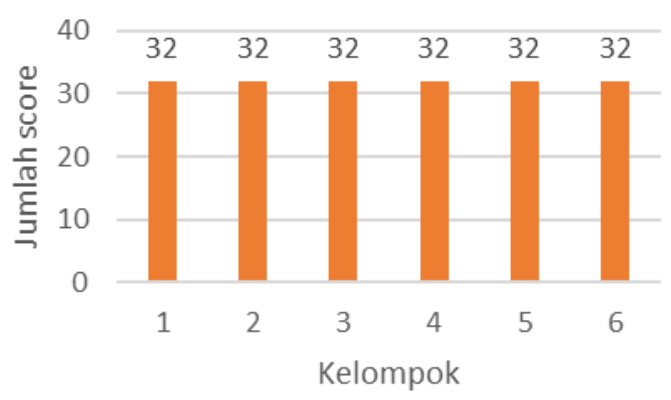

Gambar 3. Keterampilan penalaran ilmiah mahasiswa pada topik materi genetik menggunakan pemodelan

DNA dengan skor tertinggi 64

Keterampilan penalaran ilmiah (scientific reasoning) pada topik materi genetik dimiliki oleh semua kelompok. Hal ini menunjukkan bahwa penggunaan analogi model double heliks DNA pada konsep materi genetik dapat membantu memvisualisasikan dan memahamkan mahasiswa calon guru terhadap topik struktur DNA.

2) Keterampilan penalaran ilmiah mahasiswa pada

konsep pindah silang

Keterampilan penalaran ilmiah siswa pada konsep pindah silang didapat dari analogi proses pindah silang yang dibuat secara berkelompok. Profil keterampilan penalaran ilmiah pada mahasiswa dapat diamati pada Gambar 4.

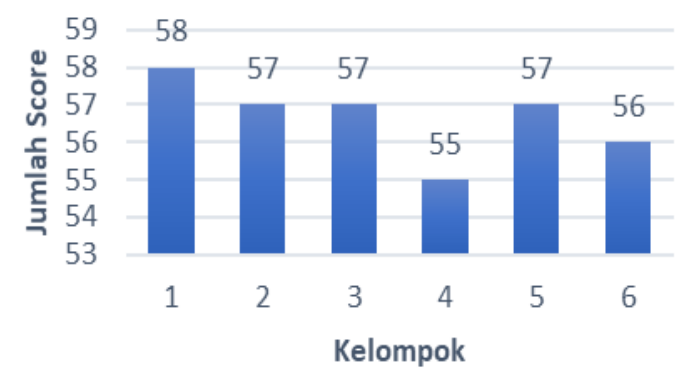

Gambar 4. Keterampilan penalaran ilmiah mahasiswa pada konsep pindah silang dengan pemodelan menggunakan lilin malam dengan skor tertinggi 64

\section{Profil keterampilan penalaran ilmiah mahasiswa calon guru}

Profil keterampilan penalaran ilmiah calon guru didapat melalui analisis secara deskriptif leveling kemampuan siswa. Indikator yang digunakan untuk mengukur keterampilan penalaran ilmiah menurut Wenning \& Vieyra (2015). Keterampilan penalaran ilmiah diukur secara individu. Wenning \& Vieyra (2015) mengkategorikan keterampilan penalaran ilmiah menjadi integrated, advances dan culminating. Level profil kemampuan penalaran ilmiah mahasiswa calon guru dapat dilihat pada Tabel 2.

Tabel 2. Profil keterampilan penalaran ilmiah calon guru

\begin{tabular}{cc}
\hline $\begin{array}{c}\text { Level keterampilan penalaran } \\
\text { ilmiah }\end{array}$ & Persentase calon guru \\
\hline Integrated & 23,5 \\
Advances & 24,2 \\
Culminating & 52,3 \\
\hline $\mathrm{n}: 37$ partisipan
\end{tabular}

Tabel 2 memperlihatkan bahwa profil keterampilan penalaran ilmiah mahasiswa calon guru tersebar dalam tiga kategori menurut Wenning \& Vierya. Sebanyak 52,3\% mahasiswa calon guru berada pada level culminating. Hasil ini diperoleh melalui penerapan analogi pada pembelajaran topik materi genetik dan pindah silang. Hasil tersebut menunjukkan bahwa analogi dapat digunakan untuk konsep-konsep genetika yang abstrak dan juga dapat menumbuhkan keterampilan penalaran ilmiah pada mahasiswa calon guru.

Penerapan analogi dalam pembelajaran genetika dapat menumbuhkan keterampilan penalaran ilmiah mahasiswa calon guru. Mahasiswa calon guru mampu mendefinisikan suatu masalah untuk dipelajari, mendefinisikan sistem yang akan dipelajari, merancang dan melakukan penyelidikan ilmiah yang terkontrol, menafsirkan data kuantitatif untuk menetapkan tahapan yang menggunakan logika, menentukan apakah yang dipilih adalah jawaban atas masalah atau pertanyaan cukup menentukan ukuran dan atau unit, meringkas tujuan logis yang membenarkan dasar kesimpulan dari bukti empiris, menggunakan penalaran kausal untuk membedakan co-insidence dari sebab dan akibat, menyimpulkan secara logis dari bukti yang empiris, menggunakan penalaran kausal untuk membedakan kebetulan dari sebab dan akibat, menggunakan menyimpulkan data dan matematika dalam pemecahan penalaran proporsional untuk membuat prediksi, menggunakan penalaran proporsional untuk membuat prediksi, menghasilkan dan mengevaluasi analogi, menghasilkan prediksi melalui proses deduksi, berpikir analogi, berpikir untuk mengasimilasi konsep dan berpikir dengan sengaja.

Terdapat berbagai manfaat dari penerapan analogi. Penerapan analogi dalam pembelajaran genetika terutama pada topik materi genetik dan pindah silang, mampu membina penalaran ilmiah dalam pendidikan - sebagai bukti meta-analitik (Engelmann et al., 2016), memecahkan masalahmasalah dengan menggunakan nalar (Kolodner et al., 2003) dan melatihkan keterampilan sintesis (Lawson, 2004) dari proses belajar genetika pada 
siswa dan siswa pun mampu berkomitmen secara rasional (Zeineddin \& Abd-El-Khalick, 2010) serta menggunakan pengetahuannya untuk berpikir dan bernalar secara rasional dalam berbagai fenomena di kehidupannya kelak (Duncan, 2007).

Tujuan dari penelitian ini adalah untuk mengetahui profil keterampilan penalaran ilmiah (scientific reasoning) pada mahasiswa calon guru. Mahasiswa calon guru dituntun untuk mengenali orientasi belajar yang bermakna, keterampilan penalaran dan perolehan pemahaman pada topik genetika yang bermakna, dan keterampilan untuk memecahkan masalah genetika. Keterampilan ilmiah yang disepakati banyak ahli terdiri dari ketepatan, kehati-hatian, mampu menggunakan alat, menjelaskan fenomena, memprediksi pengamatan, dan membuat generalisasi.

Konseptualisasi penalaran ilmiah dapat dibedakan ke dalam tiga domain penalaran ilmiah. Ketiga domain tersebut yaitu: (a) proses penemuan ilmiah; (b) berfokus pada argumentasi ilmiah; dan (c) pemahaman sifat ilmu. (Dowden, 1993) mengatakan bahwa sebuah konsep yang kuat untuk memahami penalaran ilmiah sebagai proses, kegiatan, atau praktik dalam penemuan ilmiah didasarkan pada kegiatan pemecahan masalah. Penalaran ilmiah, terdiri dari interaksi proses non-linier dalam merumuskan hipotesis, merancang eksperimen untuk menguji hipotesis, dan mengevaluasi hipotesis. Model tambahan dan kerangka penalaran ilmiah lebih lanjut menentukan kegiatan atau praktik dalam penemuan ilmiah. Dengan pernyataan-pernyataan yang telah disebutkan, maka keterampilan penalaran ilmiah merupakan keterampilan dasar yang dapat menstimulasi keterampilan-keterampilan lain seperti keterampilan berpikir kritis atau keterampilan berpikir tingkat tinggi lainnya.

Wenning (2007) memaparkan bahwa penalaran ilmiah merupakan bagian dari keterampilan penyelidikan ilmiah yang memiliki domain: 1) mengidentifikasi suatu masalah untuk diselidiki, 2) menggunakan induksi untuk merumuskan hipotesis atau model, 3) menggunakan deduksi untuk menghasilkan prediksi, 4) merancang prosedur eksperimental, 5) melakukan percobaan ilmiah, 6) observasi, atau simulasi, 7) mengumpulkan, mengorganisir, dan menganalisa data, 8) menerapkan metode numerik dan statistik, 9) menjelaskan hasil yang tidak diharapkan, dan 10) menggunakan teknologi yang tersedia untuk melaporkan, menampilkan, dan mempertahankan hasil. Kerangka kerja penalaran ilmiah mencakup keterampilan proses intelektual dan praktik ilmiah (Wenning \& Vieyra, 2015). Keterampilan proses tersebut dikategorikan menjadi peningkatan kecanggihan intelektual dan tingkat penyelidikan yang ditemukan.

Setiap tingkat dalam kecanggihan intelektual terhubung dengan Taksonomi Bloom untuk membantu membuktikan mengapa setiap keterampilan jatuh ke level tersebut. Seperti tingkat penyelidikan, Taksonomi Bloom berisi tingkat sasaran yang bergerak dari kecanggihan intelektual yang lebih rendah ke yang lebih tinggi: mengingat, memahami, menerapkan, menganalisis, mengevaluasi, dan mensintesis.

Pembelajaran genetika dengan analogi ini bisa dilakukan selama pendidikan guru preservice serta pelatihan guru in-service. Analogi ini mampu mempromosikan keterampilan untuk berpikir secara umum tentang fenomena baru dan masalah yang mungkin dihadapi siswa dalam kehidupan sehari-hari seperti pada konsep Genom organisme. Hal ini sesuai dengan tujuan utama pendidikan sains. Tujuan ini terbukti menjadi tantangan yang semakin berkembang dalam berbagai domain tujuan pembelajaran dalam genetika, seperti genetika molekuler, dimana pemahaman ilmiah lebih ditekankan lagi, sehingga penggunaan analogi dalam proses pembelajaran sangat dibutuhkan untuk diterapkan untuk mengembangkan keterampilanketerampilan lain.

Untuk mengembangkan instruksi yang lebih efektif dalam menumbuhkan penalaran generatif pada siswa, maka siswa perlu memiliki pemahaman yang baik tentang jenis pengetahuan dalam domain untuk penalaran ilmiah. Pemahaman yang terintegrasi dari deduktif - induktif atau sebaliknya induktif - deduktif dan keterampilan menentukan proporsi analogi yang tepat serta keterampilan analogi yang cermat dapat meningkatkan proses penalaran ilmiah pada siswa. Penalaran ilmiah pada konsep-konsep abstrak seperti genom organisme, materi genetik dan pindah silang mampu meningkatkan pemahaman siswa akan konsepkonsep genetika sehingga diharapkan dapat mewujudkan pemahaman mekanis pada konsepkonsep aplikatif dalam genetika molekuler.

Bentuk pengetahuan ini mewujudkan pemahaman mekanisme pusat dan entitas dalam genetika molekuler. Dengan menerapkan formulir pengetahuan khusus domain ini, para siswa mampu beralasan tentang berbagai masalah genetika yang familiar dan baru. Penulis menyajikan sebuah model kognitif yang menyoroti peran pemahaman konseptual yang kuat dalam mempromosikan penalaran generatif dalam genetika. Penalaran Analogi semakin diakui sebagai instrumen penting untuk mempromosikan perubahan konseptual dalam pembelajaran sains, terutama genetika. 


\section{Simpulan}

Penerapan analogi dalam pembelajaran genetika dapat diterapkan untuk beberapa topik yang abstrak seperti materi genetik dan peristiwa pindah silang. Penerapan analogi dalam pembelajaran genetika dapat menumbuhkan keterampilan penalaran ilmiah calon guru. Penelitian ini dapat dikembangkan penelitian yang lain terkait penerapan analogi untuk mengukur keterampilan, topik maupun media yang lain sehingga konsep-konsep genetika yang abstrak menjadi lebih mudah dipahami oleh calon guru biologi. Media pembelajaran yang digunakan dapat bervariasi guna mempermudah visualisasi beberapa konsep yang abstrak.

\section{Ucapan terima kasih}

Terima kasih kepada IAIN Syekh Nurjati Cirebon atas dukungan finansial demi terselenggarakannya penelitian ini. Terima kasih kepada SPS Universitas Pendidikan Indonesia (UPI) atas bimbingan selama melaksanakan penelitian. Terima kasih semua partisipan mahasiswa Tadris IPA Biologi IAIN Syekh Nurjati Cirebon atas partisipasinya dalam penelitian ini.

\section{Referensi}

Bello, J., Butler, C., Radavich, R., York, A., Oseto, C., Orvis, K., \& Pittendrigh, B. R. (2007). Genomics analogy model for educators (GAME): VELCRO ${ }^{\circledR}$ Analogy model to enable the learning of DNA arrays for visually impaired and blind students. The Science Education Review, 6(4), 123:1-123:12. Diambil dari https://files.eric.ed.gov/fulltext/ EJ1050923.pdf

Cavallo, A. M. L. (1996). Meaningful learning, reasoning ability, and students' understanding and problem solving of topics in genetics. Journal of Research in Science Teaching, 33(6), 625-656. https://doi.org/10.1002/(SICI)1098-2736 (199608)33:6<625::AID-TEA3>3.0.CO;2-Q

Ding, L., Wei, X., \& Mollohan, K. (2016). Does higher education improve student scientific reasoning skills? International Journal of Science and Mathematics Education, 14(4), 619-634. https://doi.org/10.1007/s10763-014-9597-y

Dowden, B. H. (1993). Logical reasoning. California: Wadsworth Pub. Co. Google Books

Duncan, R. G. (2007). The role of domain-specific knowledge in generative reasoning about complicated multileveled phenomena. Cognition and Instruction, 25(4), 271-336. https://doi.org/10.1080/073700007016323 55
Engelmann, K., Neuhaus, B. J., \& Fischer, F. (2016). Fostering scientific reasoning in education meta-analytic evidence from intervention studies. Educational Research and Evaluation, 22(5-6), 333-349. https://doi.org/10.1080/ 13803611.2016.1240089

Goldschmidt, G. (2001). A strategy for design reasoning and learning. In C. M. Eastman, W. M. McCracken, \& W. C. Newstetter (Ed.), Design knowing and learning: Cognition in design education (hal. 199). USA: Elsevier. Google Books

Janssen, F. J. J. M., \& van Berkel, B. (2015). Making philosophy of science education practical for science teachers. Science \& Education, 24(3), 229-258. https://doi.org/10.1007/s11191014-9735-5

Jiménez-Aleixandre, M. P. (2014). Determinism and underdetermination in genetics: Implications for students' engagement in argumentation and epistemic practices. Science \& Education, 23(2), 465-484. https://doi.org/10.1007/s11191012-9561-6

Kaufman, D. R., Patel, V. L., \& Magder, S. A. (1996). The explanatory role of spontaneously generated analogies in reasoning about physiological concepts. International Journal of Science Education, 18(3), 369-386. https://doi.org/ $10.1080 / 0950069960180309$

Kind, P., \& Osborne, J. (2017). Styles of scientific reasoning: A cultural rationale for science education? Science Education, 101(1), 8-31. https://doi.org/10.1002/sce.21251

Kılıç, D., \& Sağlam, N. (2014). Students' understanding of genetics concepts: the effect of reasoning ability and learning approaches. Journal of Biological Education, 48(2), 63-70. https://doi.org/10.1080/00219266.2013.837 402

Kolodner, J. L., Camp, P. J., Crismond, D., Fasse, B., Gray, J., Holbrook, J., ... Ryan, M. (2003). Problem-based learning meets case-based reasoning in the middle-school science classroom: Putting learning by design(tm) into practice. Journal of the Learning Sciences, 12(4), 495-547. https://doi.org/10.1207/ S15327809JLS1204_2

Lawson, A. E. (2004). The nature and development of scientific reasoning: A synthetic view. International Journal of Science and Mathematics Education, 2(3), 307-338. https://doi.org/10.1007/s10763-004-3224-2

Shamos, M. H. (Morris H. (1995). The myth of scientific literacy. Rutgers University Press. Google Books

Stiller, J., Hartmann, S., Mathesius, S., Straube, P., Tiemann, R., Nordmeier, V., ... Upmeier zu 
Belzen, A. (2016). Assessing scientific reasoning: A comprehensive evaluation of item features that affect item difficulty. Assessment $\&$ Evaluation in Higher Education, 41(5), 721732. https://doi.org/10.1080/02602938. 2016.1164830

Wenning, C. J. (2007). Assessing inquiry skills as a component of scientific literacy. Journal of Physics Teacher Education Online, 4(2), 2124. Diambil dari http://www.phy.ilstu.edu/ jpteo/issues/jpteo4(2)win07.pdf

Wenning, C. J., \& Vieyra, R. E. (2015). Teaching high school physics (volume 1). Author. Google Books
Woody, S., \& Himelblau, E. (2013). Understanding \&amp; teaching genetics using analogies. The American Biology Teacher, 75(9), 664-669. https://doi.org/10.1525/abt.2013.75.9.7

Zeineddin, A., \& Abd-El-Khalick, F. (2010). Scientific reasoning and epistemological commitments: Coordination of theory and evidence among college science students. Journal of Research in Science Teaching, 47(9), 1064-1093. https://doi.org/10.1002/tea.20368

Zimmerman, C. (2000). The development of scientific reasoning skills. Developmental Review, 20(1), 99-149. https://doi.org/10.1006/DREV. 1999.0497 